\title{
Nitrogen and phosphorus cycling and transformations in a prototype 'non-polluting' integrated mariculture system, Eilat, Israel
}

\author{
M. D. Krom ${ }^{1}$, S. Ellner ${ }^{2}$, J. van Rijn ${ }^{3}$, A. Neori ${ }^{4, *}$ \\ 'Department of Earth Sciences, Leeds University, Leeds LS2 9JT, United Kingdom \\ ${ }^{2}$ Biomathematics Program, Department of Statistics, North Carolina State University, Raleigh, North Carolina 27695-8203, USA \\ ${ }^{3}$ Faculty of Agriculture, The Hebrew University of Jerusalem, PO Box 12, Rehovot, Israel \\ ${ }^{4}$ Israel Oceanographic \& Limnological Research, National Centre for Mariculture, PO Box 1212, Eilat 88112, Israel
}

\begin{abstract}
An intensive mariculture system for the growth of sea bream has been developed which uses seaweed Ulva lactuca to remove dissolved nutrients ( $N$ and $P$ ) from the circulating water. This allows water to be safely recycled to the fish and results in a comparatively 'non-polluting' final effluent. As with other mariculture systems, only $\sim 25 \%$ of the food- $\mathrm{N}$ was used for fish growth. The dominant processes affecting $N$ within the system were excretion by fish of ammonia- $N(30 \%)$, dissolved organic nitrogen (DON) $(30 \%)$ and faeces-N $(10 \%)$, rapid transformation of DON to ammonia-N $(16 \%)$ in the fish tank and uptake of ammonia-N (17 to $39 \%$ ) by the seaweed (all percentages expressed relative to food input). Nitrification $(10 \%)$ competed with the seaweed for the available ammonia-N. There was only minimal uptake of nitrate by the seaweed. Anoxic conditions developed in the sedimentation tank. Denitrification $(5 \%)$ and bacterial ammonification, including sulphate reduction, were observed. The system showed only minor seasonality, probably because the major processes (food input and $U$. lactuca uptake) had only a slight dependence on temperature. Our quantitative understanding of the processes affecting $\mathrm{N}$ within the system was confirmed by a parallel study in which a computer simulation model was developed which was able to predict well the observed changes in ammonia-N, total oxidised $\mathrm{N}$ and $U$. lactuca growth. There was an excess of phosphorus in the food supplied. It was removed by the seaweed ( 9 to $21 \%$ ) but to a lesser degree than ammonia-N. The residual organic matter in the sedimentation tank was enriched in P, probably because of the presence in the food of bone meal which is resistant to bacterial decay. The final effluent discharged contained 20 to $27 \%$ of the $\mathrm{N}$ supplied (and 39 to $47 \%$ of the $\mathrm{P}$ ) which is less than half the $\mathrm{N}$ discharged from conventional mariculture technology.
\end{abstract}

KEY WORDS: Mariculture -Integrated system - Fish Seaweed - Non-polluting $\cdot$ Sustainable $\cdot$ Nutrient budget

\section{INTRODUCTION}

The development of sustainable integrated agricultural technologies is important if we are to feed an ever-growing population with minimum damage to the environment. Mariculture is one of the last major untapped food resources. Recently there has been considerable growth in this agricultural sector in western Europe and North America, mainly the culture of

\footnotetext{
- Addressee for correspondence
}

salmon in sea cages. Fish grown in mariculture systems retain only 20 to $30 \%$ of the food supplied as body flesh (Porter et al. 1987. Hall et al. 1992). The remaining 70 to $80 \%$ is excreted as either dissolved or particulate nutrients. These waste products have the potential to cause a variety of pollution problems, including reduction in oxygen content and ultimately anoxia, changes in ecosystem structure, damage to fragile ecosystems such as coral reefs (Banner 1974, Tomascik \& Sander 1985, Bell et al. 1989) and increased frequency of toxic dinoflagellate blooms (Watanabe 1991). Mariculture systems operating in this way are 
also wasteful of energy, since the excreted nutrients are high-quality and high-energy food (such as reduced $\mathrm{N}$ ) usable for other commercially valuable marine organisms. These problems have long been recognized by freshwater aquaculturists and a variety of integrated systems have been developed such as carp-mulberry bush (silkworm) culture in China, carprice-pig culture in the Far East (Pillay \& Dill 1979, Woynarovich 1979, de la Cruz et al. 1992) and integrated fish culture and vegetable growth (Rakocy \& Hargreaves 1993 ).

Over the past decade, scientists at the National Center for Mariculture in Eilat, Israel, have set out to develop integrated mariculture systems which exploit the natural advantages of the local climate (sunshine and heat; Gordin et al. 1981). Previous attempts have used phytoplankton to remove excess nutrients from the fishpond water and oysters as biofilters to provide an extra commercial crop (Gordin et al. 1981, 1990, Krom \& Neori 1989). However, in such systems the phytoplankton are subject to uncontrollable blooms and crashes caused by microflagellate grazing (Krom et al. 1989). These fluctuations cause large changes in water quality conditions, particularly in ammonia and dissolved oxygen, which can result in fish mortalities (Krom et al. 1985). Such systems also export most of the nutrients from the fishpond as a mixture of dissolved and particulate nutrients, the proportions depending on the phytoplankton bloom and crash status at the time (Krom \& Neori 1989, Neori \& Krom 1991). Under such conditions, the effluent waters from the ponds are unreliable as a food source for the second crop, bivalves, and in turn bivalves are not dependable as biofilters to clean the pollution from the system (Shpigel et al. 1993).

The use of seaweed as a biofilter was first suggested by Ryther et al. (1975). According to them, a biofilter system based on seaweed would have the potential to produce stable water quality conditions for the fish and a final effluent low in nutrient waste products. The system reported here represents a pilot study of such a sustainable mariculture system which cultures gilthead sea bream Sparus aurata in a pond coupled with tanks of seaweed Ulva lactuca. Growing fish in intensive culture loads the pond water with high fluxes of nitrogen and phosphorus. These sustain a variety of microbial and biological processes, characteristic of hypertrophic systems, which interact with one another and compete for the available nutrients (Barica \& Mur 1979). In this study we set out to determine which processes were occurring within this pilot-scale system, what was their relative magnitude throughout an annual cycle and how the different processes compete for available nutrients. These questions were addressed by means of a series of total nutrient budgets designed to identify and quantify the significant processes within the system and how they change with time. Specific experiments were carried out to locate these processes within the system and to estimate their rates.

In a parallel study, a computer simulation model of the system was developed. It represented a quantitative hypothesis about the processes controlling $\mathrm{N}$ in the system based on this study and how they interact (S. Ellner et al. unpubl.). The model was tested using 2 sets of independent data. The quality of the fit of the measured data to the model's predictions provided an estimate of how well we understand the principal processes within the system.

\section{METHODS}

Description of system. The fish-seaweed biofilter system consisted of 4 fiberglass tanks $\left(2.5 \mathrm{~m}^{3}, 3.3 \mathrm{~m}^{2}\right.$ each), 1 for fish, containing $1790 \mathrm{l}$ of seawater, and the other 3 for seaweed, containing $2130 \mathrm{l}$ each (Fig. 1). Water was circulated by an electric pump from the fishtank via a small (400 l) sedimentation tank, to the 3 seaweed tanks (designated Ulva) arranged in parallel. Water then returned to the fish tank by gravity. Screens at the end of each Ulva tank kept the seaweed from washing out. The whole system contained approximately $8600 \mathrm{l}$ of seawater which was circulated internally at a rate of 800 to $1000 \mathrm{l} \mathrm{h}^{-1}$. Each day, $2000 \mathrm{l}$ of fresh seawater was pumped into the system in 2 pulses of $1000 \mathrm{l}$ each at $08: 30$ and at 16:30 h. There was a simultaneous outflow of $1800 \mathrm{l}$ (input less evaporation and sampling; Neori et al. 1994) which flowed out via a $600 \mathrm{l}$ seaweed polishing tank to the sea. A small volume (up to $10 \mathrm{l}$ ) of water containing sludge was drained daily from the sedimentation tank.

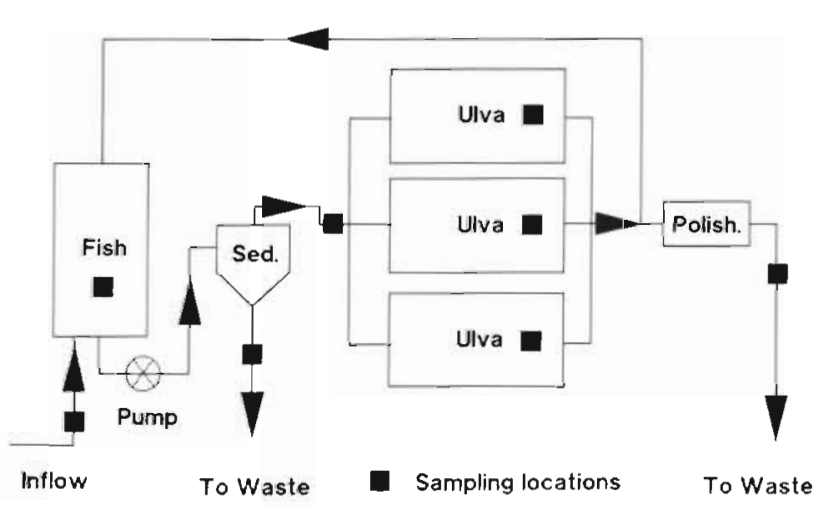

Fig. 1 Schematic diagram of the fishpond-seaweed biofilter system, showing sampling locations. Arrows indicate the direction of water flow 
Table 1. Principal analytical methods used in this study together with their performance characteristics

\begin{tabular}{|lcl|}
\hline Determined & $\begin{array}{c}\text { Coefficient of } \\
\text { variation (1s) }\end{array}$ & Method used \\
\hline Total ammonia-N & $2.0 \%$ & Krom et al. (1989) \\
Total oxidised nitrogen & $0.3 \%$ & Krom et al. (1989) \\
Nitrite & $2.1 \%$ & Krom et al. (1989) \\
Phosphate & $0.9 \%$ & Krom et al. (1989) \\
Total dissolved nitrogen & $8 \%$ at $60 \mu \mathrm{M}$ & Persulphate oxidation followed by autoanalyser method for \\
& $5 \%$ at $120 \mu \mathrm{M}$ & TOxN (Neori et al. unpubl.) \\
Total dissolved phosphorus & $13 \%$ at $30 \mu \mathrm{M}$ & Persulphate oxidation followed by autoanalyser method for \\
Particulate and solid $\mathrm{N}$ & $7 \%$ at $60 \mu \mathrm{M}$ & phosphate (Neori et al. unpubl.) \\
Particulate and solid P & $7.6 \%$ & Carlo-Erba CHN analyzer \\
& $3.8 \%$ & Roasting at 450 C followed by extraction into $1 \mathrm{M} \mathrm{HCl} \mathrm{(Krom}$ \\
\hline
\end{tabular}

In May 1991, the fish tank was stocked with approximately $23 \mathrm{~kg}$ of young Sparus aurata. The fish were initially fed daily $(08: 30 \mathrm{~h}) 600 \mathrm{~g}$ of the pelleted diet described in Krom \& Neori (1989). Fish numbers land biomass) and feeding rate were adjusted periodically so that a food ration of $600 \mathrm{~g}$ could be maintained throughout the study period. The fish had to be replaced several times during the running period, either because of excessive size or because of fish disease. The fish tank was shaded to limit photosynthetic activity and was aerated and agitated via holes in the tank base. The Ulva and polishing tanks were stocked with Ulva lactuca at initial stocking densities of 1 and $3 \mathrm{~kg}$ per tank, respectively (the optimum based on Neori et al. 1991). The seaweed was harvested weekly and immediately restocked at the original density. The experimental system was run in this mode from April 1991 until October 1993. The routine practice and performance of the system is presented elsewhere (Neori et al. 1994).

Sampling and analysis. A series of 6 intensive $24 \mathrm{~h}$ sampling periods for total nutrient budgets were carried out between October 1991 and May 1992. Each sampling began at 08:30 h and was repeated every 3 or $4 \mathrm{~h}$ until the following morning. Water samples were taken from the fish tank. (FT), the sedimentation tank (SD), each of the 3 seaweed tanks (UT1, UT2 and UT3) and the polishing tank (D) (see Fig. 1 for sampling locations). The fresh seawater inflow (IF) was sampled once per sampling period in the morning. Each water sample consisted of $1 \mathrm{l}$ for dissolved and particulate matter measurement. In addition the sump of the sedimentation tank was drained for several seconds and the entire water sample (with its sediment) collected.

The samples for dissolved nutrient determination were filtered through acid-washed GF/F filters within $1 \mathrm{~h}$ of sampling. The filtrate was divided into several subsamples. One was immediately analyzed or stored in a dark refrigerator at $4^{\circ} \mathrm{C}$, typically for $1 \mathrm{~d}$ (after a maximum of $3 \mathrm{~d}$ all these analyses were completed). Analyses were made by the automated methods summarized in Table 1 . The second subsample was immediately placed in a freezer $\left(-15\right.$ to $\left.-20^{\circ} \mathrm{C}\right)$. Although preservation tests showed that frozen samples gave similar results to the unfrozen samples, all the data used in this study were from unfrozen samples except for the very few occasions when data were obviously inconsistent with adjacent data (in time and/or space), in which case the results from the frozen samples were used. Subsamples for total dissolved nitrogen and phosphorus were also refrigerated in the dark at $4^{\circ} \mathrm{C}$. The method used combined basic oxidation for $\mathrm{N}$ and acidic oxidation for $\mathrm{P}$, in 1 sample bottle as described in detail in Neori et al. (1994). All dissolved samples were analyzed in duplicate. Samples for particulate C, N and P were filtered on pre-ashed GF/F filters. The samples were then placed in aluminum foil and frozen. Before analysis the samples were vacuum dried in a Virtis Model 25 $\mathrm{SRC}$ vacuum dryer. These samples were also analyzed in duplicate. The analytical methods used together with the relevant performance characteristics are given in Table 1.

In addition, during several of the sampling periods, other aliquots were filtered for chlorophyll determination, preserved for bacterial cell counts (using DAPI fluorescent staining; Porter \& Feig 1980) and also used for immediate live microscopic hemacytometer counts of phytoplankton and protozoa. Chlorophyll was extracted from the glass-fiber filters in $90 \%$ acetone and analyzed by the spectrofluorometric method described in Neveux et al. (1990), using a Perkin Elmer LS 5b Spectrofluorometer connected to an IBMcompatible computer. 
Table 2. Nitrogen outputs from the fishpond-seaweed system (data from $24 \mathrm{~h}$ samplings). Input flux for all samplings was $2.53 \mathrm{~mol} \mathrm{~N} \mathrm{~d}$

\begin{tabular}{|c|c|c|c|c|c|c|c|c|c|c|}
\hline \multirow[t]{2}{*}{ Date } & \multirow{2}{*}{$\begin{array}{l}\text { Fish } \\
\text { growth }\end{array}$} & \multirow{2}{*}{$\begin{array}{l}\text { Ulva } \\
\text { yield }\end{array}$} & \multirow{2}{*}{$\begin{array}{l}\text { Sediment } \\
\text { to waste }\end{array}$} & \multicolumn{7}{|c|}{ Nutrient outflow from Ulva tanks } \\
\hline & & & & Ammonia & Nitrate & Nitrite & DON & $\begin{array}{l}\text { Particulate } \\
\text { nitrogen }\end{array}$ & $\begin{array}{l}\text { Denitrif. } \\
\text { rate }\end{array}$ & Deficit \\
\hline \multicolumn{11}{|c|}{ Data in $\mathrm{mol} \mathrm{N} \mathrm{d}^{-1}$} \\
\hline October A & 0.63 & 0.68 & 0.04 & 0.02 & 0.03 & 0.29 & 0.08 & 0.19 & 0.15 & 0.43 \\
\hline October B & 0.63 & 0.58 & 0.04 & 0.02 & 0.02 & 0.24 & 0.07 & 0.19 & 0.15 & 0.59 \\
\hline November & 0.66 & 0.58 & 0.04 & 0.02 & 0.02 & 0.25 & 0.15 & 0.19 & 0.15 & 0.47 \\
\hline January & 0.53 & 0.60 & 0.04 & 0.04 & 0.08 & 0.16 & 0.08 & 0.29 & 0.15 & 0.56 \\
\hline March & 0.48 & 0.44 & 0.09 & 0.01 & 0.14 & 0.10 & 0.10 & 0.19 & 0.15 & 0.83 \\
\hline May & 0.61 & 0.99 & 0.04 & 0.02 & 0.20 & 0.05 & 0.05 & 0.16 & 0.14 & 0.29 \\
\hline \multicolumn{11}{|c|}{ Data as percentage of input flux } \\
\hline October A & 25.0 & 26.8 & 1.4 & 0.6 & 1.2 & 11.6 & 3.3 & 7.4 & 5.9 & 16.8 \\
\hline October B & 25.0 & 23.1 & 1.4 & 0.8 & 0.9 & 9.5 & 2.6 & 7.4 & 5.9 & 23.4 \\
\hline November & 26.0 & 22.9 & 1.4 & 0.9 & 0.9 & 10.0 & 5.9 & 7.4 & 5.9 & 18.8 \\
\hline January & 21.0 & 23.8 & 1.5 & 1.4 & 3.3 & 6.4 & 3.2 & 11.5 & 5.9 & 22.0 \\
\hline March & 19.0 & 17.2 & 3.5 & 0.4 & 5.7 & 3.8 & 4.1 & 7.4 & 5.9 & 32.9 \\
\hline May & 24.0 & 36.9 & 1.4 & 0.0 & 0.1 & 1.9 & 1.9 & 0.4 & 5.4 & 11.3 \\
\hline
\end{tabular}

The seaweed tanks including the polishing tank were harvested weekly. The harvest was weighed and the tanks were restocked with $3 \mathrm{~kg}$ of seaweed each. The wet yield was the total amount measured minus $3 \mathrm{~kg}$. In order to determine the dry yield of seaweed in the system, a subsample of the harvested seaweed was weighed, rinsed, dried in an oven at $70^{\circ} \mathrm{C}$, and reweighed. An aliquot of this dried subsample was subsequently analyzed for C, N and P as described in Table 1. The final polishing seaweed tank was also harvested and sampled weekly in a similar manner. The water which was drained from the sedimentation tank with the sedimented material was oven dried $\left(70^{\circ} \mathrm{C}\right)$, and the quantity of the collected particulate matter measured. A subsample of the dry material was analyzed for $\mathrm{C}, \mathrm{N}$ and $\mathrm{P}$ content.

To determine the total nutrient budget (Tables $2 \& 3$ ), the total input was calculated from $600 \mathrm{~g}$ of food $\times$ measured $N$ and $P$ content of the food. The amount of $N$ and $P$ taken up as fish growth was calculated from $N$ retention tables measured for Sparus aurata in Eilat using the same food as that used in this study (I. Lupatch unpubl.). The daily Ulva yield was calculated from the measured weekly yield assuming a constant daily growth rate. Sludge, removed from the system, was measured directly during each of the intensive

Table 3. Phosphorus outputs from the fishpond-seaweed system (data from 24 h samplings). Input flux for all samplings was $0.290 \mathrm{~mol} \mathrm{P} \mathrm{d}^{-1}$

\begin{tabular}{|c|c|c|c|c|c|c|c|}
\hline \multirow[t]{2}{*}{ Date } & \multirow{2}{*}{$\begin{array}{l}\text { Fish } \\
\text { growth }\end{array}$} & \multirow{2}{*}{$\begin{array}{l}\text { Ulva } \\
\text { yield }\end{array}$} & \multirow{2}{*}{$\begin{array}{l}\text { Sediment } \\
\text { to waste }\end{array}$} & \multicolumn{4}{|c|}{ Nutrient outflow from Ulva tanks } \\
\hline & & & & Phosphate & DOP & $\begin{array}{l}\text { Particulate } \\
\text { phosphorus }\end{array}$ & Deficit \\
\hline \multicolumn{8}{|c|}{ Data in $\mathrm{mol} \mathbf{P ~ d}^{-1}$} \\
\hline October A & 0.075 & 0.033 & 0.015 & 0.091 & 0.014 & 0.018 & 0.045 \\
\hline October B & 0.075 & 0.033 & 0.020 & 0.068 & 0.011 & 0.018 & 0.066 \\
\hline November & 0.078 & 0.030 & 0.020 & 0.070 & 0.014 & 0.018 & 0.060 \\
\hline January & 0.064 & 0.027 & 0.029 & 0.064 & 0.003 & 0.020 & 0.083 \\
\hline March. & 0.058 & 0.032 & 0.040 & 0.065 & 0.009 & 0.018 & 0.069 \\
\hline May & 0.073 & 0.061 & 0.013 & 0.066 & 0.040 & 0.013 & 0.025 \\
\hline \multicolumn{8}{|c|}{ Data as percentage of input flux } \\
\hline October A & 26.0 & 11.2 & 5.2 & 31.3 & 4.7 & 6.1 & 15.5 \\
\hline October B & 26.0 & 11.2 & 6.9 & 23.4 & 3.7 & 6.1 & 22.8 \\
\hline November & 27.0 & 10.5 & 6.9 & 24.1 & 4.8 & 6.1 & 20.7 \\
\hline January & 22.0 & 9.4 & 10.0 & 21.9 & 1.1 & 6.8 & 28.8 \\
\hline March & 20.0 & 10.9 & 13.8 & 22.5 & 3.0 & 6.1 & 23.8 \\
\hline May & 25.0 & 21.1 & 4.5 & 22.7 & 13.7 & 4.3 & 8.7 \\
\hline
\end{tabular}


sampling periods. The nutrient outflow was calculated from the average concentration of dissolved and particulate nutrients measured in the Ulva tanks at the times of water outflow $x$ measured flow rate. The denitrification rate was estimated from the observed decrease in total oxidised $\mathrm{N}$ (TOxN) values (corrected for our best estimate for nitrification rate) determined during the no-flow experiment (see below in section on sedimentation tank). The deficit was the input minus the sum of the outflows from the system.

In May 1993 an experiment was run in which the flow of water in the system was entirely stopped for $5.25 \mathrm{~h}$ (14:00 to 19:15 h). Water was sampled in the fish tank, sedimentation tank and Ulva tanks initially and then every hour from 15:15 until 19:15 h. The samples were processed in the same way as described above for the $24 \mathrm{~h}$ sampling periods.

Operating conditions of the system. Water quality was monitored throughout the sampling period on a regular basis (Neori et al, 1994). In brief, the weekly average temperature in the system ranged from $23^{\circ} \mathrm{C}$ in summer to $14^{\circ} \mathrm{C}$ during winter, with diurnal variation of up to $10^{\circ} \mathrm{C}$. Light levels over the year ranged from 120 to 190 Einsteins $\mathrm{m}^{-2} \mathrm{~d}^{-1}$. The salinity in the system increased from $40.3 \mathrm{ppt}$ (the inlet seawater) to $44.6 \mathrm{ppt}$ in the final polishing tank. Dissolved oxygen levels in the fishtank ranged from 4 to $9 \mathrm{mg}^{-1}$, with diurnal fluctuations of 1 to $2 \mathrm{mg} \mathrm{l}^{-1}$. In the Ulva tanks the dissolved oxygen levels ranged from 7 to $12 \mathrm{mg} \mathrm{l}^{-1}$, with diurnal ranges of up to $4 \mathrm{mg} \mathrm{l}^{-1}$. Particulate chlorophyll a (chl a) levels (excluding that in seaweed fronds) ranged from 1 to $4 \mathrm{\mu g} \mathrm{l}^{-1}$.

\section{RESULTS}

The input of nutrients in food was constant throughout the sampling period at $2.53 \mathrm{~mol} \mathrm{~N} \mathrm{~d} \mathrm{~d}^{-1}$ and $0.290 \mathrm{~mol} \mathrm{P} \mathrm{d}^{-1}$ (Tables $2 \& 3$ ). The $\mathrm{N}$ uptake by fish ranged from 19 to $26 \%$ of the input with a slightly higher uptake in the warmer months (May-November) than in winter (January-March). Specific growth measurements were made only occasionally during this sampling period so as not to disturb the fish unduly. Using the measured elemental composition of the fish (Lupatch unpubl.), the 2 data sets were consistent with one another. Ulva yield was 0.44 to $0.99 \mathrm{~mol} \mathrm{~N} \mathrm{~d}{ }^{-1}$ which represented 17 to $39 \%$ of the $\mathrm{N}$ input. The amount of $\mathrm{P}$ retained by the Ulva $\left(0.027\right.$ to $\left.0.061 \mathrm{~mol} \mathrm{P} \mathrm{d}^{-1}\right)$ was 9 to $21 \%$ of the total input, less as a percentage of total input than $N$. The removal of $\mathrm{N}$ to waste in the sedimentation tank was 1.4 to $3.5 \%$ of the total input. The relative fraction of $\mathrm{P}$ sedimented out in this tank was greater, at 4.5 to $13.8 \%$.
The main water quality parameter that this system was designed to control was ammonia- $\mathrm{N}$ in the fishpond. The levels of ammonia- $N$ within the system were maintained below $120 \mu \mathrm{M}$ in the fish tank and below $30 \mu \mathrm{M}$ in the Ulva tank (Fig. 2). The peak of ammonia$\mathrm{N}$ in the Ulva tank was at the end of the night while the peak of ammonia- $\mathrm{N}$ in the fish tank was at 15:00 h, $8 \mathrm{~h}$ after feeding. Neori et al. (1994) showed that this pattern of tight control of ammonia- $\mathrm{N}$ was typical of values obtained throughout the year. The amount of dissolved ammonia-N exported from the Ulva tank was low, $<0.04 \mathrm{~mol} \mathrm{~N} \mathrm{~d}^{-1}$ or $<1.4 \%$ of the input $\mathrm{N}$ flux to the fish tank. The export of dissolved organic nitrogen (DON) was 0.05 to $0.15 \mathrm{~mol} \mathrm{~d} \mathrm{~d}^{-1}$ (1.9 to $\left.5.9 \%\right)$. There was a steady flux of $\sim 0.25 \mathrm{~mol}$ TOxN d $\mathrm{d}^{-1}(\sim 10 \%)$ exported from the system (Table 2). However the relative proportion of nitrate to nitrite increased systematically throughout the sampling period (Fig. 3). The export of particulate organic $\mathrm{N}$ (PON) was steady all year at $0.2 \pm 0.04 \mathrm{~mol} \mathrm{~N} \mathrm{~d}{ }^{-1}$. The chl a content for this particulate matter was 1 to $4 \mu g \mathrm{l}^{-1}$. If one assumes a mass ratio for N/chl a of 4.4 , similar to that determined previously for phytoplankton in fish ponds in Eilat (Krom \& Neori 1989), then it is estimated that only 0.57 to $2.2 \mathrm{mmol} \mathrm{N} \mathrm{d}^{-1}$ was exported as phytoplankton and
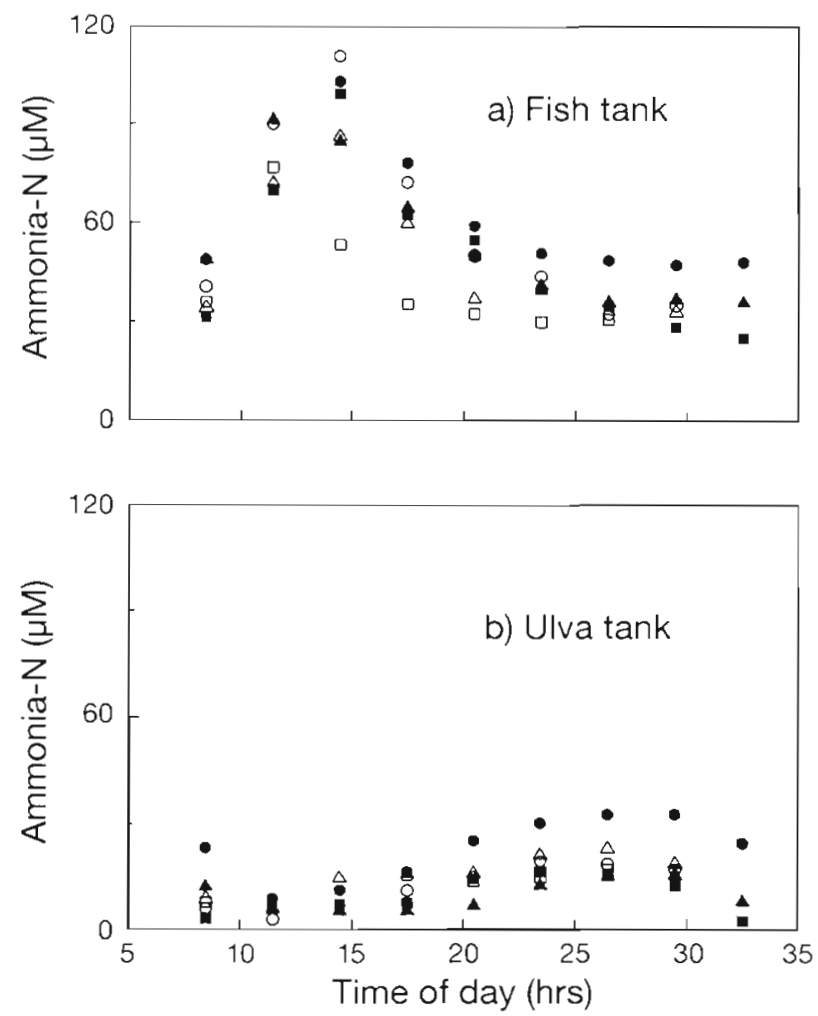

Fig. 2. Ammonia-N concentration in (a) fish tank and (b) Ulva tank during $24 \mathrm{~h}$ samplings. Each sampling was started at 08:30 h. Sampling periods are (O) October A, (口) October B,

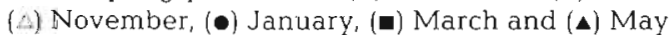




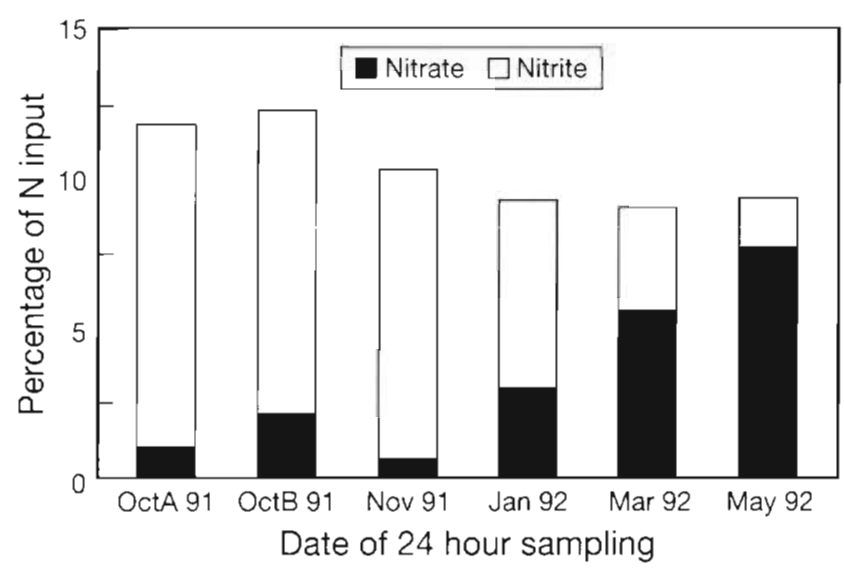

Fig. 3. Net nitrification in the system as measured by the net daily export of oxidised $\mathrm{N}$ from the system

microscopic seaweed fragments. A further quantity of $<3 \mathrm{mmol} \mathrm{N} \mathrm{d}^{-1}$ of the particulate matter was identified as bacterial cells. The microscopically determined biomasses of heterotrophic eucaryotic organisms, such as protozoa, never exceeded $1 \mathrm{mmol} \mathrm{N} \mathrm{d}^{-1}$. This export of identifiable microbes represented only a minute quantity of the total biomass exported from the system, compared to the seaweed yield of about $0.6 \mathrm{~mol} \mathrm{~N} \mathrm{~d}^{-1}$.

While it was suspected that denitrification might be a significant process within the system it was not possible to quantify it using the data from the total $\mathrm{N}$ budget. It was however found that during the no-flow experiment, denitrification in the sedimentation tank was a significant process in the system. We used the rate determined from the no-flow experiment $(0.15 \mathrm{~mol}$ $\mathrm{N} \mathrm{d}^{-1}$; see below) for all the sampling periods.

The principal export of $\mathrm{P}$ from the system was as phosphate (22 to $31 \%$ ) with smaller amounts of dissolved organic phosphorus (DOP) (1 to $13.7 \%$ ) and particulate organic $\mathrm{P}$ (4.3 to $6.8 \%)$. The amount of phosphate exported, expressed as a percentage of input, was 39 to $47 \%$, which was greater than that for ammonia- $\mathrm{N}$.

Having completed our best estimate of the total $N$ and $\mathrm{P}$ budgets, we found a consistent deficit of approximately $20 \%$ (Tables $2 \& 3$ ). One possible reason for this deficit might be that the nutrient content of the food was only measured on 1 sample which may not have been adequately representative of the entire food supplied. The only process which might contribute substantially to the $\mathrm{N}$ deficit and which we did not include in the budget was coupled nitrification-denitrification. However, given the large number of data, each with their own sampling and analytical errors, we consider this to be an acceptable deficit.

Nutrient budgets for individual chemical species were calculated for each tank every $3 \mathrm{~h}$ during the $24 \mathrm{~h}$ sampling period. The change in flux represented the net biogeochemical process occurring in that tank. We found that the rate of water recirculation was so rapid that the precision of the data as not sufficient to allow quantitative estimates of processes in each tank to be made, except for the production of ammonia- $\mathrm{N}$ by fish excretion in the fish tank and uptake of ammonia- $\mathrm{N}$ by Ulva lactuca. To solve this problem an experiment was conducted in May 1993 in which the flow of water in the system was entirely stopped for a few hours. There was a linear change in nutrient content over the first $3.25 \mathrm{~h}$ of the experiment in the fish tank and over the first 4 to $5 \mathrm{~h}$ in the sedimentation and Ulva tanks (Figs. 4 to 6 ). The net rate of change of dissolved nutrient was obtained from a regression calculated for the linear portion of the experiment. The ammonia-N change in the fish tank (14:00 to $17: 15 \mathrm{~h})$ was $45 \mathrm{mmol}$ $\mathrm{h}^{-1}$ (Fig. 4). Porter et al. (1987) showed that the excretion rate of ammonia- $\mathrm{N}$ by Sparus aurata is strongly dependent on the time since the fish were fed. The fish
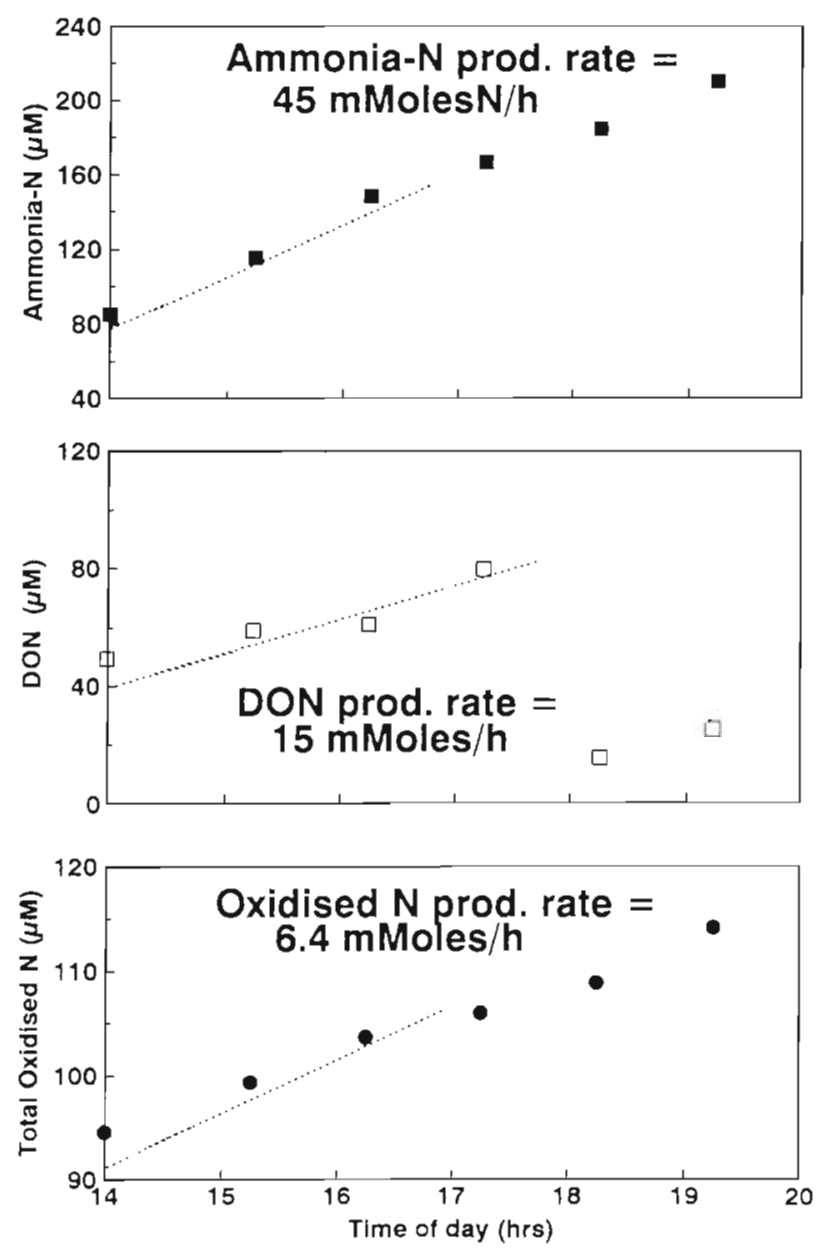

Fig 4. Accumulation of ammonia-N, DON and total oxidised $\mathrm{N}$ in the fish tank during the no-flow expenment 

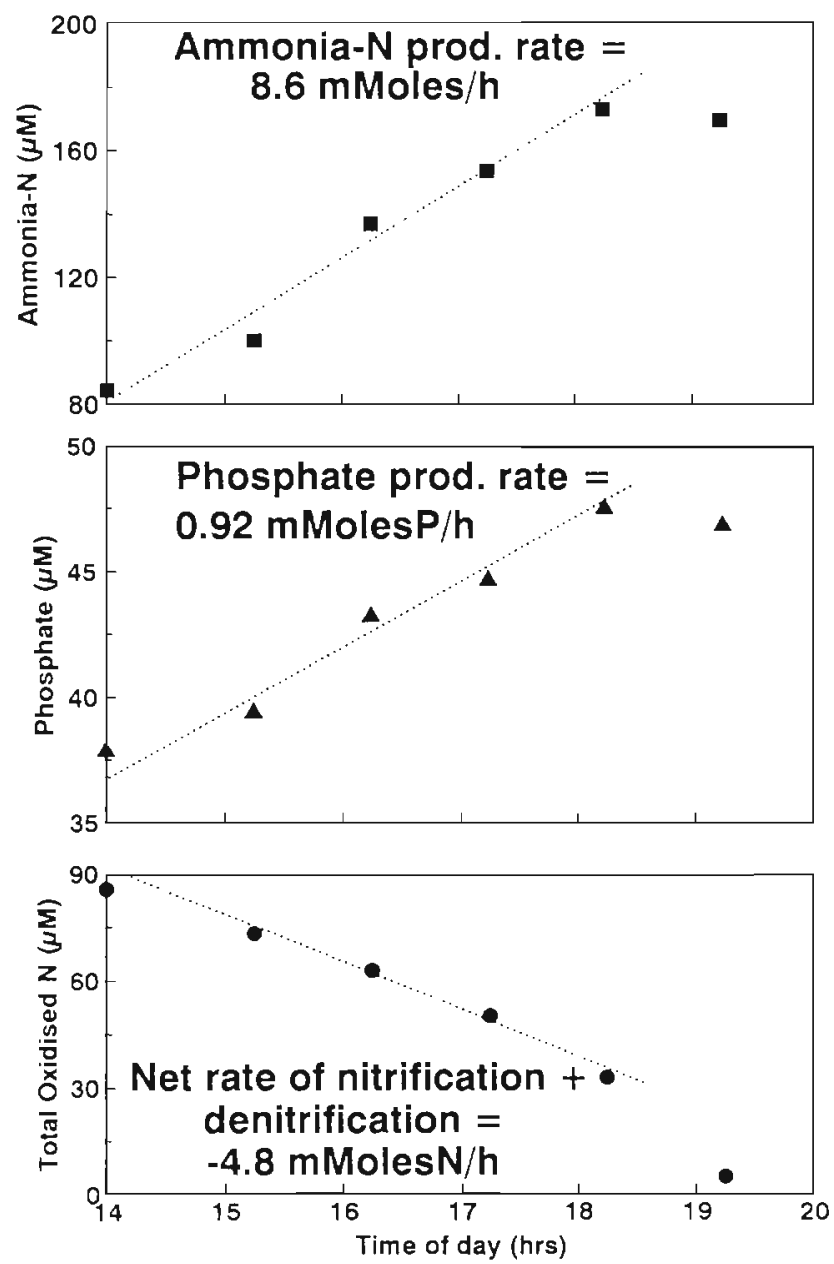

Fig. 5. Accumulation of ammonia-N, phosphate and total oxidised $\mathrm{N}$ in the sedimentation tank during the no-flow experiment

in this experiment were fed at 08:30 h and after we applied a correction based on Porter et al.'s data the calculated ammonia- $\mathrm{N}$ accumulation was $1.87 \mathrm{~mol}$ $\mathrm{N} \mathrm{d}^{-1}$, or $74 \%$ of the $\mathrm{N}$ input. During the same time period only $15 \mathrm{mmol} \mathrm{N} \mathrm{h}^{-1}$ were accumulated as DON in the fish tank. Porter et al. (1987) did not determine a time-dependent relationship of DON excretion from the fish and so a correction of the type made for ammonia- $\mathrm{N}$ was not possible. The accumulation rate of $\mathrm{DON}$ in the fish tank was thus estimated to be $0.36 \mathrm{mmol}$ $\mathrm{N} \mathrm{d}^{-1}$. This would become $0.56 \mathrm{~mol} \mathrm{~N} \mathrm{~d}^{-1}$ if the same correction was applied as for ammonia-N excretion. There was an increase in nitrate and nitrite (TOxN) in the fish tank of $6.4 \mathrm{mmol} \mathrm{N} \mathrm{h}^{-1}$. No evidence existed for any anaerobic pockets within this tank even under no-flow conditions, and thus this change corresponds to a nitrification rate of $0.17 \mathrm{~mol} \mathrm{~N} \mathrm{~d}^{-1}$.

Ammonia- $\mathrm{N}$ accumulated in the sedimentation tank at a rate of $8.6 \mathrm{mmol} \mathrm{N} \mathrm{h}^{-1}$ during the first $4 \mathrm{~h}$ of the no-flow experiment, equivalent to $0.21 \mathrm{~mol} \mathrm{~N}$ $\mathrm{d}^{-1}$ (Fig. 5) When the sedimentation tank was drained there was a strong smell of hydrogen sulphide in the 'drainage'. The accumulation of phosphate within this tank was closely correlated with ammonia-N (Fig. 5). The observed rate of $0.92 \mathrm{mmol}$ $\mathrm{P} \mathrm{h}^{-1}$ was equivalent to a daily rate of $0.022 \mathrm{~mol} \mathrm{P}$ $\mathrm{d}^{-1}$ TOxN in the sedimentation tank decreased linearly over the first $4.25 \mathrm{~h}$ of this experiment at a rate of $-4.8 \mathrm{mmol} \mathrm{N} \mathrm{h}^{-1}$ which is equivalent to a rate of $0.12 \mathrm{~mol} \mathrm{~N} \mathrm{~d}^{-1}$. The only process which could be responsible for such a decrease is denitrification. This is likely to be an important process in this tank since there is a high concentration of nitrate within the tank $(\sim 90 \mu \mathrm{M}$ initially, decreasing to $<30 \mu \mathrm{M}$ after $4.25 \mathrm{~h}$ ) and there were anaerobic pockets containing labile organic matter in the tank. The observed denitrification rate in the sedimentation tank is probably a net rate for nitrification + denitrification. We expect that nitrification was also occurring in the sediment tank because its upper portion was kept constantly aerobic by the inflow of aerated water from the fishtank, and we know that nitrification was occurring in all other aerobic parts of the system where ammonia$\mathrm{N}$ was present. If we assume that the nitrification rate is proportional to the surface area of the tank wall in contact with water, then based on the rates in the fish and seaweed tanks we estimate a nitrification rate of $0.03 \mathrm{~mol} \mathrm{~N} \mathrm{~d}^{-1}$. Thus we estimated that the denitrification rate in the sedimentation tank was $0.15 \mathrm{~mol} \mathrm{~N} \mathrm{~d}^{-1}$. This value was used in the budget calculations and in the computer simulation model (Ellner et al. unpubl.).

The accumulation of TOxN in each of the 3 Ulva

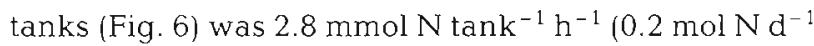
for the 3 tanks together). The ammonia- $N$ concentration within the tanks ranged from 1 to $73 \mu \mathrm{M}$. At these

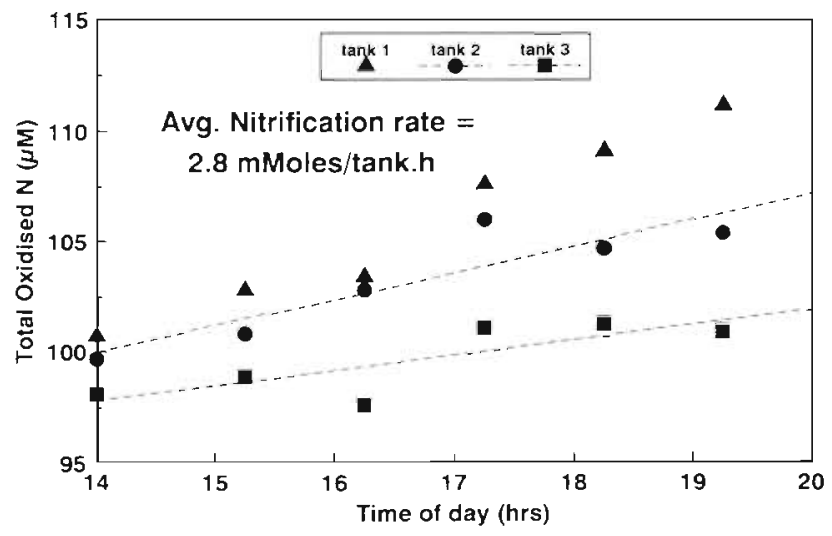

Fig. 6. Accumulation of total oxidised $\mathrm{N}$ in each of the 3 Ulva tanks during the no-flow experiment. Sampling was started at $08: 30 \mathrm{~h}$ 
ammonia- $\mathrm{N}$ levels and for the time period considered, the uptake of TOxN by Ulva lactuca was insignificant (Neori et al. unpubl. data). We can thus consider this rate of TOxN accumulation to be the nitrification rate in those tanks.

\section{DISCUSSION}

\section{Fish tank}

As in most intensive aquaculture systems, the major source of nutrients was from the fish food after it was excreted by the fish. The input of nutrients with the water inflow was negligible. Between 74 and $81 \%$ of the food- $N$ was excreted as ammonia- $N$, DON or as faeces with the remainder retained by the fish for growth. Similar values for the percentage of fish food retained for growth by Sparus aurata were obtained in laboratory experiments (Porter et al. 1987) and in measurements on fish held in ponds and sea cages (Porter et al 1986, Krom \& Neori 1989). These values are similar for the retention of $\mathrm{N}$ by other species of fish used in mariculture such as salmon trout and sea bass (Steffens 1981, Alexis et al. 1986, Hidalgo \& Alliot 1988). Thus it is an intrinsic characteristic of mariculture that even when operated at maximum efficiency for growth of fish, large quantities of nutrients are exported from the fish holding tank or cage.

Porter et al. (1987) estimated that $\sim 10 \%$ of the $\mathrm{N}$ supplied to Sparus aurata in the food was excreted as faeces with approximately equal amounts of the remaining $60 \%$ being excreted as ammonia-N (30\%) and as DON (30\%). In the no-flow experiment, most of the dissolved $\mathrm{N}$ produced in the fish tank was as ammonia-N (74\% of the $\mathrm{N}$ supplied). This included the fraction accumulated as ammonia-N (67\%) and the increase in $\mathrm{TOxN}$ due to nitrification (7\%). By contrast only $14 \%$ of the nitrogen was exported as DON. Similarly during all the $24 \mathrm{~h}$ experiments the flux of DON from the fish tank was $\sim 26 \%$ of the total dissolved $\mathrm{N}$ flux compared to the $50 \%$ predicted by Porter et al. (1987). It is concluded that bacterial ammonification was occurring in the fish tank which rapidly converted DON to ammonia-N. A similar rapid conversion of DON to ammonia- $N$ was observed by Krom \& Neori (1989) in experiments on full scale $\left(100 \mathrm{~m}^{3}\right)$ intensive fishponds. This can be of considerable practical importance since ammonification can convert DON, which is often unutilizable by algae (Flynn \& Butler 1986), to ammonia- $N$, the favored $N$ source of many seaweeds. Details of these rapid transformations involving DON are not well studied in hypertrophic systems but as these data show they may be very important.

\section{Sediment tank}

The sedimentation tank was included in the system to trap particulate matter, particularly fish faeces, while maintaining a flow of oxygenated nutrient-rich water between the fish tank and Ulva tank. It was predicted from the results of Porter et al. (1987) and Krom \& Neori (1989) that $10 \%$ of the $\mathrm{N}$ budget should be found as faeces. In fact only about $3 \%$ was found as sedimented material in this tank. The sediment was drained from the tank once per day which meant that particulate organic matter (POM) accumulated for an average of $12 \mathrm{~h}$ and a maximum of $24 \mathrm{~h}$. In the no-flow experiment, $0.2 \mathrm{~mol}$ ammonia- $\mathrm{N} \mathrm{d} \mathrm{d}^{-1}$ was produced within the sedimentation tank (Fig. 5). If it is assumed that all the ammonia- $\mathrm{N}$ produced in the sedimentation. tank is the result of bacterial ammonification of POM (there was no significant change in DON), then the total amount of POM in the tank (measured as drained POM plus respired) was $0.24 \mathrm{~mol} \mathrm{~N} \mathrm{~d}^{-1}$ which is close to the amount of faeces predicted by Porter et al. (1987) as being produced by the fish.

Although the input and outflow of the sedimentation tank remained permanently oxic (Neori et al. 1994), parts of the sedimentation tank became anoxic, as evidenced by a strong smell of hydrogen sulphide in the drained material. During the no-flow experiment (May 1993), there was a decrease in TOxN equivalent to 0.12 mol $\mathrm{N} \mathrm{d}^{-1}$, which (when corrected for our best estimate for nitrification in the upper layers of this tank) corresponded to a denitrification rate of $0.15 \mathrm{~mol}$ $\mathrm{N} \mathrm{d}^{-1}$. This rate was equivalent to a loss of nitrogen $\left(\mathrm{N}_{2}\right)$ from the system equivalent to $5 \%$ of the total $\mathrm{N}$ supplied (Table 2, Fig. 5). This is probably a minimum value for the entire system. If there had been any other pockets of anoxia, such as in the connecting pipes or in the bottom of the Ulva tanks, we would expect denitrification to have occurred there as well. Sulphate reduction and possibly methane production also occurred within the sedimented organic matter in the bottom of this tank.

During the no-flow experiment $0.022 \mathrm{~mol} \mathrm{P} \mathrm{d}^{-1}$ were produced in the sedimentation tank. This corresponds to an N/P ratio of $\sim 9$ for the organic matter which had decomposed. The measured N/P ratio of the organic matter which was drained from the sedimentation tank was only 4 to 5 (Tables $2 \& 3$ ). It was estimated that only $\sim 30 \%$ of the organic matter which sediments in this tank was actually drained from the system. The remainder was decomposed. This suggests that the residual organic matter is richer in phosphorus than the organic matter which has been oxidized. This is the opposite of the situation typically found in natural systems where P is the more labile element (e.g. Krom \& Berner 1981). The food which was fed to the fish con- 
tained a significant amount of fish meal which contains bone material (G. Kissil \& I. Lupatch pers. comm.). Bone meal contains apatite which is not only indigestible to the fish but also resistant to bacterial decomposition. It is unknown at present whether this apatite and other resistant phosphorus phases are ultimately available to be recycled into the environment via microbial decay (Cowey \& Cho 1991).

\section{Ulva tank}

The principal process which removed nutrients from the water column was uptake by seaweed. Most of the ammonia- $\mathrm{N}$ supplied to the Ulva tank was removed, often down to levels of less than $10 \mu \mathrm{M}$. Cohen \& Neori (1991) have shown that with $\mathrm{N}$ fluxes of up to $6 \mathrm{~g} \mathrm{~N} \mathrm{~m}^{-2}$ $\mathrm{d}^{-1}$, the rate of ammonia- $\mathrm{N}$ uptake by the seaweed and its $\mathrm{N}$ content are dependent on the flux. The fluxes in the present system ranged from 0.3 to $3.5 \mathrm{~g} \mathrm{~N} \mathrm{~m}^{-2} \mathrm{~d}^{-1}$. Consequently, the biofilters had an important buffering capacity for ammonia- $N$ levels in the system, with higher fluxes resulting in higher uptake rates. The seaweeds also removed significant amounts of phosphate from the water, though there was always excess phosphate present. In our system, Ulva lactuca strongly preferred ammonia- $N$ over oxidized $N$ (see also DeBusk et al. 1986). Nitrite and nitrate were taken up by the seaweed when ammonia- $\mathrm{N}$ concentrations were below 1 to $2 \mu \mathrm{M}$, whic happened only in the polishing tank receiving the system's outflow (Neori et al. 1994). The preference to ammonia uptake by seaweeds even in the presence of high oxidised $\mathrm{N}$ concentrations is a well-known phenomenon (e.g. Wallentinus 1984). Only under very special conditions of nutrient concentrations and light do specimens of Ulva rigida, collected from the sea, show nitrate uptake in the presence of ammonia-N (Corzo \& Niell 1992) The seaweed
$\mathrm{N}$ content, which was up to $6 \%$ of dry weight for the ammonia-N-grown seaweed in the Ulva tank, was only up to $4 \%$ for the oxidized-N-grown plants in the polishing tank. This is in agreement with our earlier findings on the dependance of $U$. lactuca $N$ content on ammonia flux (Cohen \& Neori 1991).

Table 4 compares the calculated uptake of ammonia$\mathrm{N}$ in the Ulva tanks for each of the $24 \mathrm{~h}$ sampling periods (corrected for an average nitrification rate of $0.15 \mathrm{~mol} \mathrm{~N} \mathrm{~d}^{-1}$ ) with the measured Ulva lactuca harvest. There was a close comparability confirming that the major process removing ammonia-N from the water column was uptake by $U$. lactuca. The computer simulation model estimates the uptake of ammonia-N by $U$. lactuca using an equation based on Cohen \& Neori (1991) and Neori et al. (1991). The predicted uptakes rates in the model are also similar to these values (Ellner et al, unpubl.) confirming that our quantitative understanding of this component of the system is valid.

\section{Nitrification}

Total oxidized nitrogen (nitrite + nitrate) accumulated in the system due to bacterial nitrification. The conditions necessary for this process to occur, oxygen-rich water with a significant quantity of ammonia-N, were present throughout the system except for the bottom of the sedimentation tank where oxygen was absent. From the $24 \mathrm{~h}$ budgets it was calculated that the total amount of nitrification within the system was relatively constant throughout the year at about $10 \%$ of the total $N$ input (Fig. 3). At the beginning of the year most of the oxidized nitrogen was nitrite while as the year progressed the proportion of nitrite decreased relative to nitrate. The system was monitored for a further year (1993-4) and it was found that nitrate continued to be the principal oxidized nitrogen species exported (Neori et al. 1994). Thus the change from nitrite to nitrate was not related to temperature or to season. Various factors might have caused the observed nitrite accumulation in the system. Nitrite accumulation has been observed as a succession that occurs as the nitrification system develops with initial conversion of ammonia- $N$ to nitrite and, after a certain lag period, conversion of nitrite to nitrate. This sequence is common in hypertrophic systems (Sharma \& Ahlert 1977). The lag period varies from a few days in freshwater systems (Shilo 
\& Rimon 1982) to a few weeks in marine systems (Manthe et al. 1984). However, in our system nitrite accumulated for several months. It is unlikely that this was caused by a simple succession of ammonia- $\mathrm{N}$ and nitrite oxidising bacteria. Low oxygen concentrations have been shown to cause nitrite accumulation by both nitrifiers (Helder \& de Vries 1983, van Rijn \& Rivera 1990) and denitrifiers (Tiedje 1988). Zones of low oxygen were present in the system (sedimentation tank, bottom of fish and Ulva tanks). Laboratory incubation of samples from these zones resulted in nitrite accumulation (O. Dvir et al. unpubl.). The question as to the unusually slow disappearance of nitrite with the proceeding of the growth season remains open and deserves future attention.

Data from the no-flow experiment (Figs. 4 \& 6) estimated the net nitrification rate to be $0.15 \mathrm{~mol} \mathrm{~N} \mathrm{~d}^{-1}$ in the fish tank and $0.05 \mathrm{~mol} \mathrm{~N} \mathrm{~d}^{-1}$ in each of the 3 Ulva tanks. Preliminary observations (Dvir et al. unpubl.) suggested that nitrification occurred primarily on the walls of the UIva tank, although some also occurred on suspended particles in the water and on the seaweed's surface. From the relationship between the total rates for seaweed growth and TOxN accumulation, it is clear that the nitrifiers could not outcompete the seaweed for the use of ammonia- $\mathrm{N}$, probably because lack of colonization surface area. The area of the wet solid surfaces available for colonization by nitrifiers is likely to be an important practical determinant in the competition for ammonia- $\mathrm{N}$ between the seaweed and the bacteria.

\section{Computer model results}

In a parallel study to this, we developed a computer simulation model which was designed to represent a quantitative hypothesis about the processes controlling $\mathrm{N}$ cycling in this system, specified which processes were dominant, the rates of those processes, and the factors controlling those processes (Ellner et al. unpubl.). The model was developed using the data and understandings presented in this paper. The model was then tested against 2 independant data sets, one in which the flow rate was decreased from $20000 \mathrm{ld}^{-1}$ to $8450 \mathrm{l} \mathrm{d}^{-1}$ and the second in which the feeding rate was halved for $3 \mathrm{~d}$. The match between the simulation model and these independent experimental results was extremely good for a process-based ecological model. These latter tests involved independent data that were not used in developing the model or estimating its parameters. The model was also able to describe the annual and diel cycles in the experimental system under normal operating conditions. Consequently, these results are a strong indication that we have identified the key processes determining the inorganic $\mathrm{N}$ balance in the system, and the factors that control those processes.

\section{Seasonality of the system}

The system had comparatively little seasonal variability in the principal outputs which were monitored in this study (Tables $2 \& 3$ ). This observation is a priori somewhat surprising since the temperature variation between winter and summer is greater than $10^{\circ} \mathrm{C}$. It is known that several of the processes which occur in the system have $Q_{10}$ values greater than 2 to 3 , such as sulphate reduction and denitrification (Knowles 1982, Westrich \& Berner 1988). The primary controlling factors in this system were the fish excretion rate and the Ulva lactuca uptake rate. Fish excretion is primarily controlled by the amount of food supplied and only to a much smaller degree by the temperature of the water (I. Lupatch unpubl.). Likewise the U. lactuca uptake was controlled primarily by the flux of ammonia-N through the Ulva tanks (Cohen \& Neori 1991) except on very cloudy winter days which are unusual in Eilat. Duke et al. (1989) also observed that N uptake in Ulva curvata depends on $\mathrm{N}$ supply rate rather than on temperature. Nitrification rate, the next most important process, is controlled principally by the amount of active surface area available for bacterial colonization and to a lesser extent by the concentration of ammonia-N flowing over that surface. Denitrification and sulphate reduction seem to be controlled principally by the amount of labile organic matter present in anoxic sites within the system. This, in turn, is controlled by the fish food input which was constant during this study. Sensitivity analysis of the simulation model indicates that changes in the rates of these processes (nitrification, denitrification, sulphate reduction) caused by temperature variations would induce far smaller percentage changes in water quality in the system (50 to $90 \%$ smaller for TOxN, 80 to $99 \%$ smaller for ammonia- $\mathrm{N}_{i}$ Ellner et al. unpubl.). The resulting prediction, that $T O x N$ levels should show greater seasonal variation than ammonia- $\mathrm{N}$, is borne out by the experimental results (Ellner et al. unpubl.).

\section{Pollution output from the system}

The fishpond-seaweed system was designed to control water quality in the fish tank and to reduce the pollutant (nutrient) output into the environment. Because the total amount of fish produced by various mariculture system per $\mathrm{kg}$ of food fed is comparable, the percentages exported from various mariculture systems can simply be compared (Fig. 7). Hall et al. (1992) found that $72 \%$ of the nutrients supplied to fish in sea cages was lost to the environment, principally in dis- 
Seacage system (Hall et al. 1992)
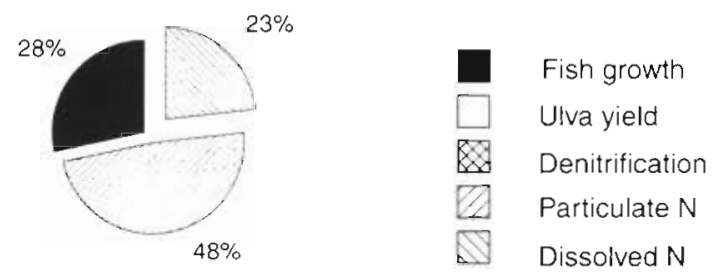

Fishpond-phytoplankton system (bloom; Krom \& Neori 1989)

Fishpond-seaweed system (this study)

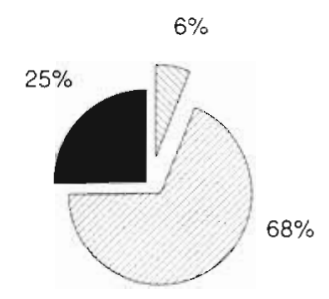

Fishpond-phytoplankton system (crash; Krom \& Neori 1989)
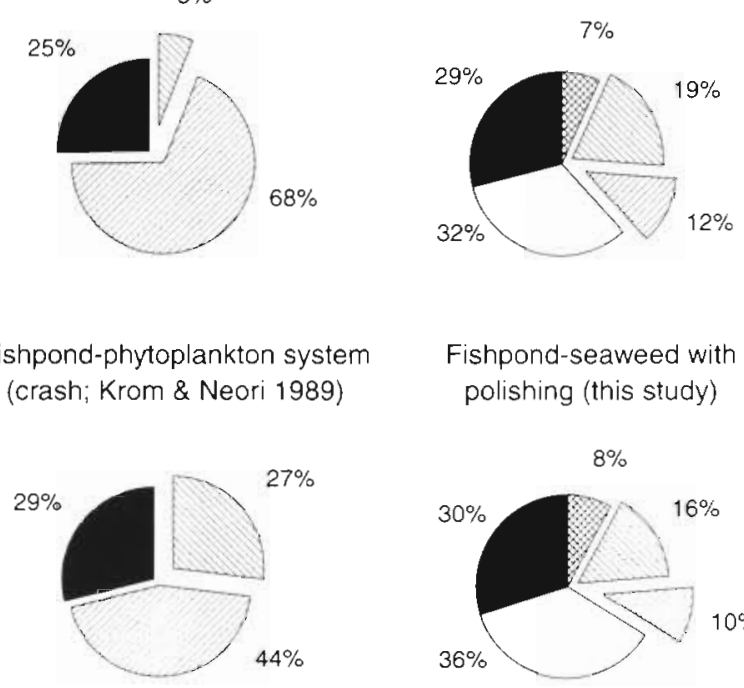

Fishpond-seaweed with polishing (this study)

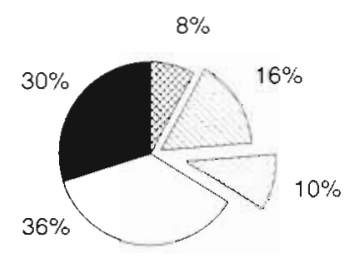

Fig. 7 Pie diagrams showing the proportion of $\mathrm{N}$ retained and exported as pollution from a sea cage system, a fishpondphytoplankton system (bloom and crash conditions), and the fishpond-seaweed system with and without the polishing step

solved forms. These nutrients are in part simply diluted and exported from the region of the cages or accumulated as organic-rich deposits beneath the cages. The impact of such systems on the environment is generally only monitored by the extent of this organic-rich deposit. Other effects such as changes in the local ecology are more difficult to quantify and are often ignored. The quantity of nutrients exported from the fishpond-phytoplankton system is similar to that lost from the sea cages ( 71 to $74 \%$ ). However because the plankton can be used for bivalve culture there is a possibility of growing a second crop which will remove part of the particulate matter and also provide an additional commercial return (Shpigel et al. 1993). The problem is that the uncontrollable bloom and crash cycle as well as the type of phytoplankton which grow make it problematic to grow a bivalve crop. The fishpond-seaweed system only loses 20 to $27 \%$ of the nitrogen input to the environment $31 \%$ if the deficit in $\mathrm{N}$ is not included). There was an additional crop of sea lettuce Ulva lactuca which is of commercial value. Sea lettuce is eaten directly as food, particularly in the Far East. It also can be used to cultivate marine invertebrate macroalgivores such as abalone, which are prized food in many parts of the world.

While the output stream contained less nutrients than other comparable intensive mariculture systems, it still contained more dissolved and particulate nutrients, especially phosphate, than is considered desirable. In this pilot plant we used a small (600 l) tank with Ulva lactuca as a polishing stage. While this did result in a further reduction of the nutrient load (from 31 to $26 \%$ ) in the effluent, it was not very efficient. The ammonia- $N$ level in the stream to the polishing tank was low with most of the $\mathrm{N}$ in the form of oxidised nitrogen. Since U. lactuca does not incorporate nitrate very efficiently (Wallentinus 1984, DeBusk et al. 1986), neither nitrate nor phosphate were removed from the outflow efficiently. Now that the characteristics of the effluent stream are known more precisely, it would be possible to design a polishing stage specifically to reduce further the load of nitrate, particulate $\mathrm{N}$ and phosphate to the levels necessary to avoid approaching the accommodative capacity of the receiving environment.

Acknowledgements. We thank D. Zuber, O. Dvir, R. Rabinowitch, M. Ucko, N. Gordon, R. Bin-Nun and P. Davison for their help with sampling and analysis and I. Lupatch and $D$. Angel for valuable advice and discussions. We thank $\mathrm{H}$. Gordin and $\mathrm{G}$. Kissel for their support and encouragement. The manuscript was written after M.D.K arrived at the Department of Earth Sciences, Leeds University, and he thanks Professor J. Cann for the generous use of the facilities of the department. This work was supported by BARD research grant no. 1-1634-89, by the Negev-Arava Fund for Research and Development, by the Israeli Ministries for Energy and Infrastructure and for Science and Technology (Grants 3035189 and 3035292 to A.N.).

\section{LITERATURE CITED}

Alexis, M. N., Theochari, V., Papaparaskeva-Papoutsoglou, E. (1986). Effect of diet composition and protein level on growth, body composition, haematological characteristics and cost of production of rainbow trout (Salmo gairdneri). Aquaculture 58: 75-85

Banner, H. A. (1974). Kaneoha Bay, Hawaii: urban pollution and a coral reef ecosystem. Proc. 2nd int coral Reet Symp. 2: $685-702$

Barica, J., Mur, L. R. (1979). Hypertrophic ecosystems. In: Barica, J., Mur, L. R. (eds.) Developments in hydrobiology, Vol. 2, Hypertrophic ecosystems. Dr W. Junk, The Hague

Bell, P. R. F., Greenfield, P. E., Hawker, D., Connel, D. (1989). The impact of waste discharges on coral reef regions. Water Sci. Technol. 21(1): 121-130

Cohen, I., Neori, A. (1991). Ulva lactuca biofilters for marine fishpond effluent. 1. Ammonia uptake kinetics and nitrogen content. Botanica mar. 34: 475-482 
Corzo, A., Niell, F. X. (1992). Inorganic nitrogen metabolism in Ulva rigida illuminated with blue light. Mar Biol. 112: $223-228$

Cowey, C. B., Cho, C. Y. (1991). Nutritional strategies \& aquaculture waste. University of Guelph, Guelph

DeBusk, T A., Blakeslee, M., Ryther, J. H. (1986). Studies on the outdoor cultivation of Ulva lactuca L. Botanica mar. 29 $381-386$

de la Cruz, C. R., Lightfoot, C., Costa-Pierce, B. A., Carangal, V. R., Bimbao, M. P. (1992). Rice-fish research and development in Asia. ICLARM Conf. Proc. 24, ICLARM, Manila

Duke, C. S., Litaker, W., Ramus, J. (1989). Effects of temperature, nitrogen supply and tissue nitrogen on ammonium uptake rates of the chlorophyte seaweeds Ulva curvata and Codium decorticatum. J. Phycol. 25: 113-120

Flynn, K. J., Butler, I. (1986). Nitrogen sources for the growth of marine microalgae: role of dissolved free amino acids. Mar. Ecol. Prog. Ser. 34: 281-304

Gordin, H., Krom, M. D., Neori, A., Popper, D., Porter, C., Shpigel, M. (1990). Intensive integrated seawater tish ponds: fish growth and water quality. In: Rosenthal, $H_{\text {., }}$ Sarig. S. (eds.) Research in modern aquaculture. Special Publ. No. 11, European Aquaculture Soc., Bredene, p. $45-64$

Gordin, H., Motzkin, F., Hughes-Games, W. L., Porter, C. (1.981). Seawater mariculture ponds - an integrated system. In: Rosenthal, H., Oren, O. H. (eds.) Intensive mariculture. Special Publ. No. 6. European Aquaculture Soc., Bredene, p. 1-14

Hall, P. O. J., Holby, O., Kollberg, S., Samuelsson, M. O (1992). Chemical fluxes and mass balances in a marine fish cage farm. IV Nitrogen. Mar. Ecol. Prog. Ser. 89: $81-91$.

Helder, W., de Vries, R. T. P. (1983). Estuarine nitrite maxima and nitrifying bacteria (Ems-Dollard Estuary). Neth. J. Sea Res. 17: $1-18$

Hidalgo, F., Alliot, E. (1988). Influence of water temperature on protein requirement and protein utilization in juvenile sea bass, Decentrarchus labrax. Aquaculture 72: 115-129

Knowles, R. (1982). Denitrification. Microb. Rev. 46: 43-70

Krom, M. D. Berner, R. A. (1981). The diagenesis of phosphorus in a nearshore marine sediment. Geochim. Cosmochim. Acta 45: 207-216

Krom, M. D., Erez, J., Porter, C. B., Ellner, S. (1989). Phytoplankton nutrient uptake dynamics in earthen marine fishponds under winter and summer conditions. Aquaculture 76: 237-253

Krom, M. D., Neori, A. (1989). A total nutrient budget for an experimental intensive fishpond with circularly moving seawater. Aquaculture 83: 345-358

Krom, M. D., Porter, C., Gordin, H. (1985). Causes of fish mortalities in semi-intensively operated seawater ponds in Eilat, Israel. Aquaculture 49: 159-177

Manthe, D. P., Malone, R. F., Kumar, S. (1984). Limiting factors associated with nitrification in closed blue crab shedding systems. Aquaculture Engineering 3: 119-140

Neori, A., Cohen, I, Gordın, H. (1991). Ulva lactuca biofilters for marine fishpond effluent. II Growth rate, yield, and C:N ratio. Botanica mar. 34: 483-489

Neori, A., Ellner, S. P., Krom, M. D., Boyd, C. E. (1994). Use of macroalgae to solve water quality problems in intensively cultured marine fishponds. Find Report for BARD project I-1634-89. Volcani Institute, Rehovot

Neori, A., Krom, M. D. (1991). Nitrogen and phosphorus budgets in an intensive marine fishpond: the importance of microplankton. In: Cowey, C. B., (ho, C. Y (eds.) Nutri-

This article was submitted to the editor tional strategies \& aquaculture waste. University of Guelph, Guelph, p. 223-230

Neveux, J., Delmas, D., Romano, J. C., Algarra, P., Ignatiades, L., Herbland, A., Morand, P., Neori, A., Bonin, D., Barbe, J., Sukenik, A., Berman, T (1990). Comparisons of chlorophylls and phaeopigment determinations by spectrophotometric, fluorometric, spectrofluorometric and HPLC methods. Mar. microb. Food Webs 4:217-238

Pillay, T V. R., Dill, W. A. (1979). Advances in aquaculture. FAO and Fishing News Books Ltd, Farnham

Porter, C., Krom, M. D., Gordin, H. (1986). Effect of water quality on the growth rate of Sparus aurata in marine fishponds. Aquaculture 59: 299-315

Porter, C. P., Krom, M. D., Robbins, M. G., Bricknell, L. Davidson, A. (1987). Ammonia excretion and total N budget for gilthead seabream (Sparus aurata) and its effect on water quality conditions. Aquaculture 66: 287-298

Porter, K. G., Feig, Y S. (1980). The use of DAPI for identifying and counting aquatic microflora. Limnol. Oceanogr. 25: $943-948$

Rakocy, J. E., Hargreaves, J. A. (1993). Integration of vegetable hydroponics with fish culture: a review. In: Wang, J.-K. (ed.) Techniques for modern aquaculture. American Society of Agricultural Engineers, East Lansing, MI, p. $112-136$

Ryther, J. H., Goldman, J. C., Gifford, C. E., Huguenin, J. E., Wing, A. S., Clarner, J. P., Williams, L. D., Lapointe, B. E. (1975). Physical models of integrated waste recycling marine polyculture systems. Aquaculture 5: 163-177

Sharma, B., Ahlert, R. C. (1977). Nitrification and nitrogen removal. Water Res. 11: $897-925$

Shilo, M., Rimon, A. (1982). Factors which affect the intensification of fish breeding in Israel. 2. Ammonia transformation in intensive fishponds. Bamidgeh 34: 101-114

Shpigel, M., Neori, A., Popper, D. M., Gordin, H. (1993). A proposed model for 'environmentally clean' land-based culture of fish, bivalves and seaweeds. Aquaculture 117 $115-128$

Steffens, W. (1981). Protein utilization by rainbow trout (Salmo gairdneri) and carp (Cyprinus carpio) a brief review. Aquaculture 23: 337-345

Tiedje, J. M. (1988). Ecology of denitrification and dissimilatory nitrate reduction to ammonium. In: Zehnder, A. J. (ed.) Biology of anaerobic microorganisms. John Wiley \& Sons, Inc., New York, p. 179-244

Tomascik, T., Sander, F. (1985). Effects of eutrophication on reef building corals: growth rate and reef building coral Montastrea annularis. Mar. Biol. 87. 143-155

van Rijn, J., Rivera, G. (1990). Aerobic and anaerobic biofiltration in an aquaculture unit - nitrite accumulation as a result of nitrification and denitrification. Aquacult. Eng. 9: $217-234$

Wallentinus, 1. (1984). Comparisons of nutrient uptake rates for Baltic macroalgae with different thallus morphologies. Mar. Biol. 80: 215-225

Watanabe, T. (1991). Past and present approaches to aquaculture waste management in Japan. In: Cowey, C. B., Cho, C. Y (eds.) Nutritional strategies \& aquaculture waste. University of Guelph, Guelph, p. 137-154

Westrich, J., Berner, R. A. (1988). The effect of temperature on rates of sulphate reduction in marine sediments. Geomicrobiol. J. 6: 99-117

Woynarovich, E. (1979). The feasibility of combining animal husbandry with fish farming, with special reference to duck and pig production. In: Plllay, T V. R., Dill, W. A. (eds.) Advances in aquaculture. FAO and Fishing News Books Ltd, Farnham

Manuscript first received: June 20,1994

Revised version accepted: November 10, 1994 